\title{
Corrosion Behavior of Galvanized Steel with Organic Coatings Containing Metallic Powders
}

\author{
Hiroyuki Ogata $^{1) *}$ and Hiroki Habazaki ${ }^{2)}$ \\ 1) Planning Department, Functional Materials Solution Division, JFE Techno-Research Corp. \\ 2) Division of Applied Chemistry, Faculty of Engineering, Hokkaido University \\ * Corresponding Author : 1 Kawasaki-cho, Chuo-ku, Chiba, 260-0835, Japan \\ E-mail: h-ogata@jfe-tec.co.jp
}

\begin{abstract}
Recently, the authors reported the improved corrosion resistance of the electro-galvanized steel coated with epoxy resin organic layers by the simultaneous additions of flaky $\mathrm{Al}$ and particulate Ni powders for the use in fuel tanks. In order to understand the roles of $\mathrm{Ni}$ and $\mathrm{Al}$ powders in the coatings on the corrosion behavior of the coated electro-galvanized steel, the electro-galvanized steel was coated with epoxy resin layers containing either $\mathrm{Ni}$ or $\mathrm{Al}$ powders, and their corrosion behavior was examined by the corrosion immersion tests in aqueous solution containing formic acid, acetic acid and $\mathrm{NaCl}$, potentiodynamic polarization measurements, electrochemical impedance spectroscopy (EIS), and oxygen gas and water vapor permeation measurements. Both $\mathrm{Ni}$ and $\mathrm{Al}$ powders in the organic coatings accelerated the corrosion. The potentiodynamic polarization curves disclosed the increased anodic and cathodic currents and the EIS study showed the reduced coating resistance by the addition of $\mathrm{Ni}$ or $\mathrm{Al}$ powders. Findings in this study suggested that the improved corrosion resistance of the coatings containing both $\mathrm{Al}$ and $\mathrm{Ni}$ powders were not simply explained by the corrosion behavior of the coated steel containing only $\mathrm{Ni}$ or $\mathrm{Al}$ powders and a possible synergistic effect of $\mathrm{Ni}$ and $\mathrm{Al}$ powders in improving the corrosion resistance is discussed.
\end{abstract}

Key words : corrosion, organic coating, metal powder, galvanized steel, degraded gasoline resistance

\section{Introduction}

Terne (Pb-Sn alloy) coated steel sheets have been widely used for automotive fuel tanks. ${ }^{1)}$ In order to reduce the harmful substances of $\mathrm{Pb}$ and $\mathrm{Cr}(\mathrm{VI})$, environmentallybenign galvanized steel sheets with organic coatings were developed. The coatings consist of a thin organic film of approximately $1 \mu \mathrm{m}$ thickness on the outer surface of tank and a $3-\mu \mathrm{m}$-thick organic film containing metallic powders (particulate $\mathrm{Ni}$ and flaky $\mathrm{Al}$ powders) on the inner surface (fuel side) of tank. The outer organic film secures the lubrication property and the corrosion resistance, and the inner organic film containing metallic powders is formed to satisfy both weldability and inner surface corrosion resistance. ${ }^{2)}$

Corrosion protection properties of organic coatings containing metallic powders were examined in the decades. Epoxy coatings containing 10 vol\% $\mathrm{Al}$ powders were prepared on carbon steel and galvanized steel, and their corrosion behavior was examined in $3 \% \mathrm{NaCl}$ using electrochemical impedance spectroscopy (EIS). ${ }^{3), 4)}$ It was reported that the $\mathrm{Al}$ powders improved the corrosion resistance of carbon steel because of cathodic protection and precipitation of corrosion products of Al. The corrosion products filled the pores of organic coating, improving the barrier nature of the coating. In contrast, the corrosion protection of the coating on the galvanized steel was less satisfactory and hence severe corrosion was reported. Nikravesh et al. added micaceous iron oxide
(MIO) and $\mathrm{Al}$ powders to epoxy-polyamide coatings on a mild steel for corrosion protection, and they reported that the powders improved the corrosion resistance and the $\mathrm{Al}$ powders were more effective than $\mathrm{MIO}$ in improving the corrosion resistance in $\mathrm{NaCl}$ solution. ${ }^{5)}$ Cathodic disbonding of polymer coating was also improved by the addition of $\mathrm{MIO}$ and $\mathrm{Al}$ powders. Arman et al. reported that partial replacement of Zn-rich epoxy coating with MIO and lamellar Al powders improved the corrosion resistance of steel. ${ }^{6)}$ However, in this case, they reported that the MIO-loaded coating showed better corrosion protection compared with the Al-loaded coating. Thus, the corrosion behavior of powder-containing organic coatings appears to be rather complex.

Inside of automobile fuel tanks is a corrosive environment, containing aqueous solution including formic acid, acetic acid and sea salt. These organic acids are derived from oxidation of alkenes, which are main components of gasoline. ${ }^{7)}$ Thus, fuel tank materials must have sufficient corrosion resistance as well as weldability, which is required to introduce welding process of the coated galvanized steel to construct fuel tanks. As discussed above, the epoxy coatings containing both $\mathrm{Ni}$ and Al powders, showing satisfactory weldability and corrosion protection properties, have been commercially used for fuel tank, ${ }^{2}$ but the corrosion protection characteristics were still unclear. Recently, we examined the corrosion behavior of a galvanized steel coated with epoxy resin films containing various concentrations of particulate $\mathrm{Ni}$ and flaky $\mathrm{Al}$ powders in an aqueous solution 
containing $100 \mathrm{ppm}$ formic acid, $100 \mathrm{ppm}$ acetic acid and $83 \mathrm{ppm} \mathrm{NaCl}$ at $40^{\circ} \mathrm{C}^{8)}$ We found that the particulate $\mathrm{Ni}$ powder in the epoxy resin coating accelerated corrosion because of galvanic corrosion between a $\mathrm{Ni}$ and a $\mathrm{Zn}$ layer and increased gas diffusion owing to the presence of voids in the epoxy resin around $\mathrm{Ni}$ powders. However, the addition of flaky $\mathrm{Al}$ powders together with $\mathrm{Ni}$ powders improved the corrosion resistance. The simultaneous addition of $\mathrm{Ni}$ and $\mathrm{Al}$ powders appeared to suppress the galvanic corrosion and the improved gas barrier properties due to the labyrinth effect of the flaky $\mathrm{Al}$ powders was also likely to improve the corrosion resistance.

In the present study, for a better understanding of the role of the $\mathrm{Ni}$ and $\mathrm{Al}$ powders on the corrosion behavior of electro-galvanized steel coated with epoxy resin films, the $\mathrm{Ni}$ and $\mathrm{Al}$ powders were added to the organic epoxy resin films separately and the corrosion behavior of the coated electro-galvanized steel was examined by corrosion immersion tests, SEM-EDS observations of the corroded specimens, potentiodynamic polarization and EIS studies, and gas permeation measurements in more details. The separate addition of $\mathrm{Al}$ powders reduced the corrosion resistance of the coated galvanized steel as well as the addition of $\mathrm{Ni}$ powders. A synergistic role of the simultaneous additions of $\mathrm{Ni}$ and $\mathrm{Al}$ powders on the corrosion resistance of the organic coatings is discussed in this study.

\section{Experimental}

\subsection{Specimen materials}

Electro-galvanized steel sheet with a trivalent chromium process (TCP) coating was used in this study. The coated steel sheet specimen was prepared by Standard Testpieces Co. and a NIPPON HYOMEN KAGAKU, Tryner TR-177AB $\mathrm{Cr}$ (III) coating solution was used for the TCP coating. Approximately $40 \mathrm{~g} \mathrm{~m}^{-2}$ of $\mathrm{Zn}$ was deposited on the coldrolled steel sheet, which was $0.8 \mathrm{~mm}$ thick. The TCP coating of approximately $40 \mathrm{mg} \mathrm{m}^{-2}$ was formed by a dipping method. After the TCP coating, the specimen was heat-treated at $100^{\circ} \mathrm{C}$ for $10 \mathrm{~s}$. Epoxy resin (ADEKA, EM0718) coatings containing either particulate Ni powders of 3-7 $\mu \mathrm{m}$ size (Vale Japan, Nickel Powder Type123) or flaky $\mathrm{Al}$ powders of $18 \mu \mathrm{m}$ in long diameter, $5 \mu \mathrm{m}$ in short diameter and $1 \mu \mathrm{m}$ thickness (Toyo Aluminium, Aluminum Paste $1700 \mathrm{NL}$ ) were prepared by a bar coating method. After heat treatment at $150^{\circ} \mathrm{C}$ for $15 \mathrm{~s}$, the coating thickness was approximately $3 \mu \mathrm{m}$. The amount of Al powders added to the epoxy resin changed from 0 to $40 \mathrm{phr}$ and the amount of Ni powders added to epoxy resin changed from 0 to $70 \mathrm{phr}$. Here, "phr" is used as an abbreviation for "per hundred resin" . For example, the notation showing that $\mathrm{Ni}$ addition was " $40 \mathrm{phr}$ " means that 40 parts of $\mathrm{Ni}$ by weight was added to 100 parts of epoxy resin.

\subsection{Corrosion tests}

Fig. 1 shows the schematic illustration of the corrosion tests. The coated specimens were cut to $30 \mathrm{~mm}$ x $80 \mathrm{~mm}$ in size for the corrosion tests and the backside and edges of the specimens were masked with protective tape to expose an area of $20 \mathrm{~mm} \times 70 \mathrm{~mm}$. A corrosive aqueous solution ( $\mathrm{pH}$ 3.2) containing $100 \mathrm{ppm}$ of formic acid, 100 ppm of acetic acid and $83 \mathrm{ppm}$ of $\mathrm{NaCl}$ was used in this study. This solution was set in a glass container so as to immerse about $2 / 3$ area of the specimen, and the container was sealed with a plastic wrap to prevent a decrease of the volatile component in the corrosive solution. The corrosion tests were performed in an electric furnace to keep the solution temperature at $40 \pm$ $1^{\circ} \mathrm{C}$. After immersion for $350 \mathrm{~h}$, the specimens were removed, washed with water and dried under hot air. The corroded specimens were then photographed, and the corrosion resistance was evaluated by obtaining the corroded area ratio by binarization.

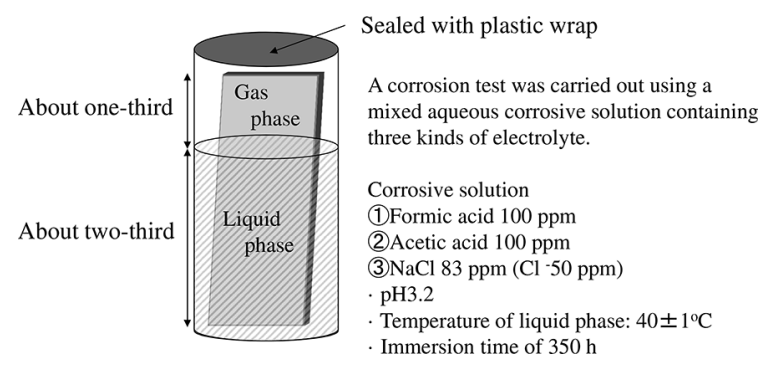

Fig. 1 Schematic illustration of the corrosion tests.

\subsection{Surface and cross-sectional observations}

For cross-sectional observations of the coated specimens before and after the corrosion tests, the specimens were embedded in resin after Pt-Pd alloy vacuum deposition on the surface, and then polished mechanically. Surface and cross-sections were observed using a Hitachi, S-4800 field emission gun scanning electron microscope (SEM) operated at an accelerating voltage of $5.0 \mathrm{kV}$. When performing elemental mapping by EDS, the accelerating voltage of $15.0 \mathrm{kV}$ was used.

\subsection{Analysis of amount of metal eluted into corrosive solution}

The corrosive solutions after the corrosion tests were analyzed using a Thermo Fisher Scientific, ELEMENT 2 type inductively coupled plasma mass spectrometer (ICP$\mathrm{MS}$ ) to quantify the dissolved amounts of $\mathrm{Ni}, \mathrm{Fe}$ and $\mathrm{Al}$. The analysis of the dissolved $\mathrm{Zn}$ was performed using a Shimadzu, ICPS-8100 inductively coupled plasma optical emission spectrometer (ICP-OES). The analytical conditions for ICP-MS and ICP-OES were summarized in Table 1. 
Table 1 Conditions used for ICP-MS and ICP-OES analyses.

\begin{tabular}{ccc}
\hline & ICP-MS & ICP-OES \\
\hline Analyzed elements & $\mathrm{Al}, \mathrm{Ni}, \mathrm{Fe}$ & $\mathrm{Zn}$ \\
\hline Plasma output $(\mathrm{W})$ & 1250 & 1200 \\
\hline Ar carrier gas rate $\left(\mathrm{L} \mathrm{min} \mathrm{m}^{-1}\right)$ & 0.80 & 0.80 \\
\hline Measured mass number $(\mathrm{m} / \mathrm{z})$ & $27(\mathrm{Al}), \mathrm{Fe}(56), 60(\mathrm{Ni})$ & - \\
\hline Measured wavelength $(\mathrm{nm})$ & - & $206.191(\mathrm{Zn})$ \\
\hline Internal standard & $\mathrm{Sc}(\mathrm{m} / \mathrm{e}=45)$ & - \\
\hline Integration time $(\mathrm{s})$ & 0.25 & 5 \\
\hline Number of scans & 9 & -
\end{tabular}

\subsection{Measurements of oxygen and water vapor permeability of coatings}

For the oxygen gas and water vapor permeation measurements, epoxy resin coatings containing $\mathrm{Ni}$ or $\mathrm{Al}$ powders were painted on a polyimide film (Kapton $500 \mathrm{H}$ manufactured by Du Pont-Toray Co. Ltd.) of $125 \mu \mathrm{m}$ thickness by a wire bar coating method. We used an O-well, Omegatrans gas permeation measurement system for both oxygen gas and water vapor permeation measurements. The oxygen permeability of the metallic powder-containing resin layer was measured by the method described below under the condition of a measurement area of $40 \mathrm{~mm} \phi, 40^{\circ} \mathrm{C}, 90 \% \mathrm{RH}$ and 100 $\mathrm{kPa}$ of oxygen.

(i) Measurement of oxygen permeability of polyimide film $(125 \mu \mathrm{m})$ : Permeability rate A

(ii) Measurement of oxygen permeability of polyimide film $(125 \mu \mathrm{m})+$ Metallic powder-containing resin layer $(30 \mu \mathrm{m})$ : Permeability rate B

The oxygen gas barrier nature was evaluated from the difference of the permeability rates $\mathrm{A}$ and $\mathrm{B}(\triangle \mathrm{OPR}=\mathrm{A}-\mathrm{B})$ . The water vapor permeability was also measured under the same condition with the oxygen permeability and the difference of the water vapor permeability $(\Delta \mathrm{WPR}=\mathrm{A}-\mathrm{B})$.

\subsection{Electrochemical polarization measurements}

Electrochemical anodic and cathodic polarization curves of the coated specimens were measured using a Hokuto-Denko, HZ-5000 electrochemical system. A three electrode cell with a $\mathrm{Pt}$ counter electrode, an $\mathrm{Ag} / \mathrm{AgCl}$ (saturated $\mathrm{KCl}$ solution) reference electrode and an aqueous electrolyte containing $100 \mathrm{ppm}$ formic acid, 100 ppm acetic acid and $83 \mathrm{ppm} \mathrm{NaCl} \mathrm{ppm}$ at $\mathrm{pH} 3.2$ and $20^{\circ} \mathrm{C}$ was used. Prior to the polarization, the coated specimens were immersed in the electrolyte for 15 min to obtain relatively stable opencircuit potential. The potential sweep rate was $1.0 \mathrm{mV} \mathrm{s}^{-1}$.

\subsection{Electrochemical Impedance Spectroscopy}

The electrochemical impedance spectroscopy (EIS) was also used in this study to elucidate the corrosion behavior. The EIS measurements were performed in the electrolyte same as the immersion tests and polarization measurements, but the electrolyte temperature was $20^{\circ} \mathrm{C}$. The EIS data were obtained using an Ivium, Compactstat potentiostat/galvanostat with FRA facilities at an open circuit potential with an $\mathrm{AC}$ amplitude of $10 \mathrm{mV}$ (rms). The obtained data were analyzed using a ZSimpWin software.

\section{Experimental results}

\subsection{Corrosion tests}

Fig. 2 shows the surface appearance of the corroded specimens with various amounts of $\mathrm{Ni}$ powders after the corrosion tests for $350 \mathrm{~h}$. The corrosion of the Ni-free specimen was less significant and the corroded area ratio estimated from the image analysis was only $8.3 \%$. The addition of $\mathrm{Ni}$ powders increases the corroded area, reaching to $100 \%$ (entire surface) at $70 \mathrm{phr} \mathrm{Ni}$. In particular, the severe corrosion is also found in the vaporexposed area in addition to the entire corrosion of the immersed area when the $\mathrm{Ni}$ content is increased to $70 \mathrm{phr}$. Thus, the corrosion of the coated electro-galvanized steel

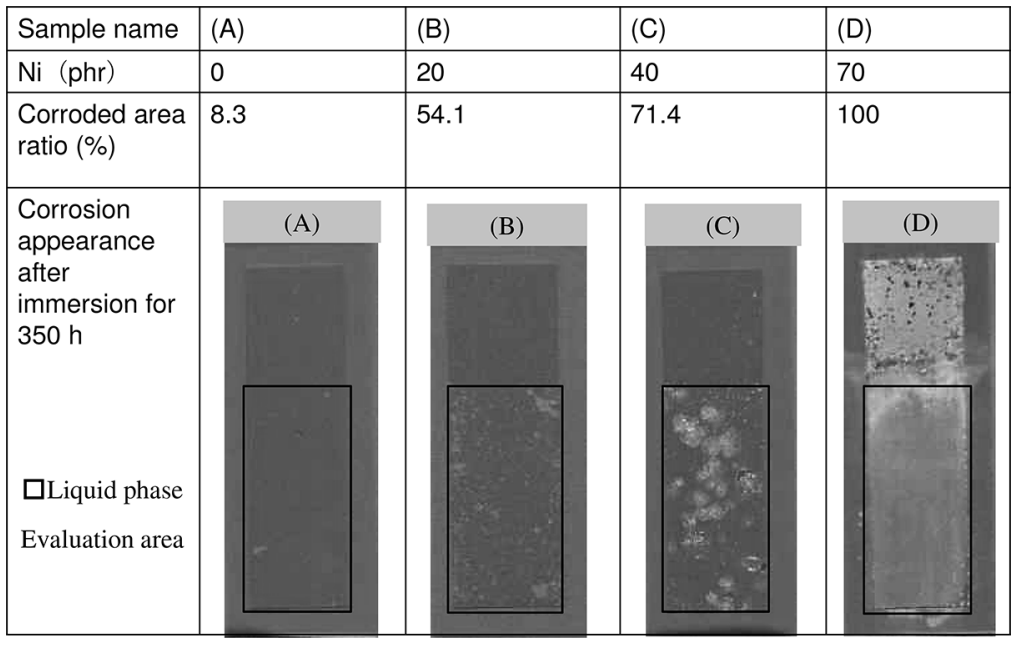

Fig. 2 Surface appearance of the samples (A) to (D) immersed in the corrosive solution containing $100 \mathrm{ppm}$ formic acid, $100 \mathrm{ppm}$ acetic acid and $83 \mathrm{ppm}$ $\mathrm{NaCl}$ at $40^{\circ} \mathrm{C}$ for $350 \mathrm{~h}$ (Online version in color.). 
is highly accelerated by the addition of Ni powders. In contrast, when $\mathrm{Al}$ powders are added, the corroded area is not clearly observed (Fig. 3). However, compared with the non-corroded region of the Al-free sample, the Aladded specimens show slightly light appearance uniformly on the entire surface, suggesting possible uniform formation of corrosion products, which is discussed later in detail.

The corrosion of the coated specimens was further examined by SEM observations. Fig. 4 shows surface and cross-section of the electro-galvanized steel with the epoxy coating containing $20 \mathrm{phr}$ Ni. The specimen was immersed in the corrosive solution for $350 \mathrm{~h}$, but the observed region in Fig. 4 was beneath the protective tape mask. Thus, no severe corrosion was found in this region, but the presence of many small voids in the zinc layer suggested the corrosion of the $\mathrm{Zn}$ layer even beneath the mask (Fig. 4 (a)). The epoxy coating on the Zn layer is $\sim 3 \mu \mathrm{m}$ thick, but the thickness increases to the size of powders around the particulate Ni powders of 5-6 $\mu \mathrm{m}$ in diameter. The surface observation of the coated specimen (Fig. 4 (b)) discloses that $\mathrm{Ni}$ powders are not completely covered with the epoxy resin and partly exposed to the corrosive solution. Since the Ni powders $(5-6 \mu \mathrm{m}$ in diameter) are larger than the thickness of the coating $(\sim 3 \mu \mathrm{m})$, many $\mathrm{Ni}$ powders appear to contact with a $\mathrm{Zn}$ layer, generating galvanic couple in the corrosive environment. The plus sign position in Fig. 4 (b) was analyzed by EDS, and the EDS spectrum, shown in Fig. 4 (c), reveals the presence of $\mathrm{Ni}$.

Surface of the coated specimen containing $20 \mathrm{phr} \mathrm{Ni}$ after immersion in the corrosive solution for $350 \mathrm{~h}$ was also observed, and Fig. 5 (a) shows an example of the obtained SEM images. Powdery corrosion product is formed in the square area and the powders are rich in $\mathrm{Zn}$ as seen in the EDS spectrum (Fig. 5 (c)) of the area 1 in Fig. 5 (b). The corrosion product is formed near the Ni

\begin{tabular}{|c|c|c|c|c|}
\hline Sample name & $(\mathrm{E})$ & $(F)$ & (G) & $(\mathrm{H})$ \\
\hline Al (phr) & 0 & 5 & 15 & 40 \\
\hline $\begin{array}{l}\text { Corroded area } \\
\text { ratio }(\%)\end{array}$ & 8.3 & 0 & 0 & 0 \\
\hline $\begin{array}{l}\text { Corrosion } \\
\text { appearance } \\
\text { after } \\
\text { immersion for } \\
350 \mathrm{~h}\end{array}$ & (E) & (F) & (G) & $(\mathrm{H})$ \\
\hline 口Liquid phase & & & & \\
\hline Evaluation area & 5 & & & \\
\hline
\end{tabular}

Fig. 3 Surface appearance of the samples (E) to (H) immersed in the corrosive solution containing $100 \mathrm{ppm}$ formic acid, $100 \mathrm{ppm}$ acetic acid and $83 \mathrm{ppm}$ $\mathrm{NaCl}$ at $40^{\circ} \mathrm{C}$ for $350 \mathrm{~h}$ (Online version in color.).
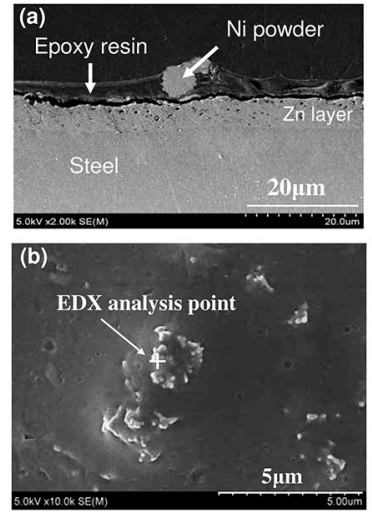

(c)

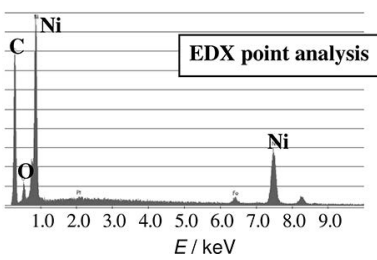

Fig. 4 Scanning electron micrographs of (a) cross-section and (b) surface of the sample (B) beneath the corrosion protection immersed in the corrosive solution containing $100 \mathrm{ppm}$ formic acid, $100 \mathrm{ppm}$ acetic acid and $83 \mathrm{ppm}$ $\mathrm{NaCl}$ at $40^{\circ} \mathrm{C}$ for $350 \mathrm{~h}$ and (c) EDS spectrum of the marked point in (b).

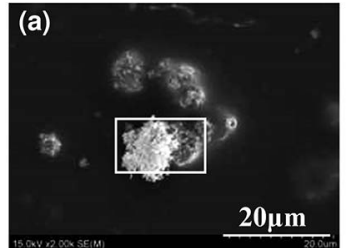

(c)

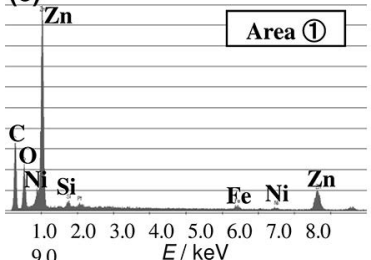

Fig. 5 (a,b) Scanning electron micrographs of surface of the sample (B) with $20 \mathrm{phr} \mathrm{Ni}$ immersed in the corrosive solution containing $100 \mathrm{ppm}$ formic acid, $100 \mathrm{ppm}$ acetic acid and $83 \mathrm{ppm} \mathrm{NaCl}$ at $40^{\circ} \mathrm{C}$ for $350 \mathrm{~h}$ and EDS spectra of the marked (c) area 1 and (d) point 2 in (b). (d)

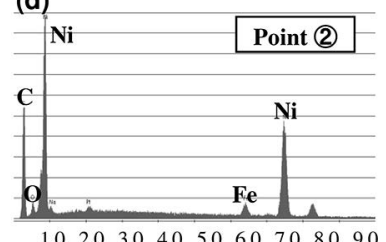

$\begin{array}{lllllllllllll}1.0 & 2.0 & 3.0 & 4.0 & 5.0 & 6.0 & 7.0 & 8.0 & 9.0\end{array}$ 5.0
$E / \mathrm{keV}$ powder, which is confirmed by the EDS analysis (Fig. $5(\mathrm{~d})$ ) of the plus sign position 2 in Fig. 5 (b). Because of the absence of corrosion products in other region of Fig. 5 (a), the corrosion of $\mathrm{Zn}$ layer was accelerated by the $\mathrm{Ni}$ powder due to the galvanic couple between $\mathrm{Ni}$ and $\mathrm{Zn}$.

Cross-sections of corroded regions of the same specimen were also observed by SEM (Fig. 6). A large corrosion product (areas 1 and 2) of $>20 \mu \mathrm{m}$ size is developed above the Ni powder (area 3 ). The corrosion product in the areas 1 and 2 consists mainly of $\mathrm{Zn}$ species, as shown in Figs. 6(b) and 6(c). The EDS spectrum of the area 3 (Fig. 6(d)) clearly indicates that the particle of the area 3 is $\mathrm{Ni}$. Because of severe 


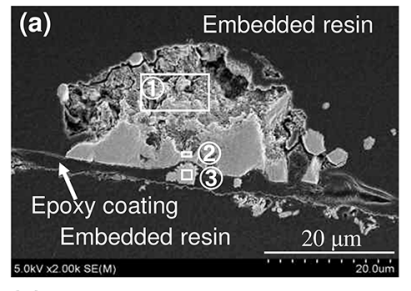

(c)

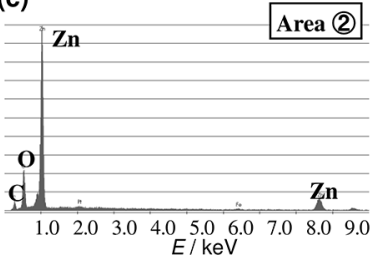

(b)

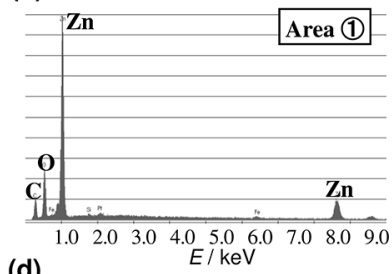

(d)

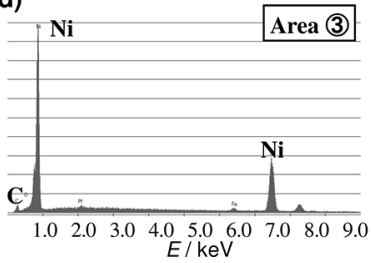

Fig. 6 (a) Scanning electron micrograph of a cross-section of the sample (B) with $20 \mathrm{phr} \mathrm{Ni}$ immersed in the corrosive solution containing $100 \mathrm{ppm}$ formic acid, $100 \mathrm{ppm}$ acetic acid and $83 \mathrm{ppm} \mathrm{NaCl}$ at $40^{\circ} \mathrm{C}$ for $350 \mathrm{~h}$ and EDS spectra of the marked areas (b) 1, (c) 2 and (d) 3 in (a).
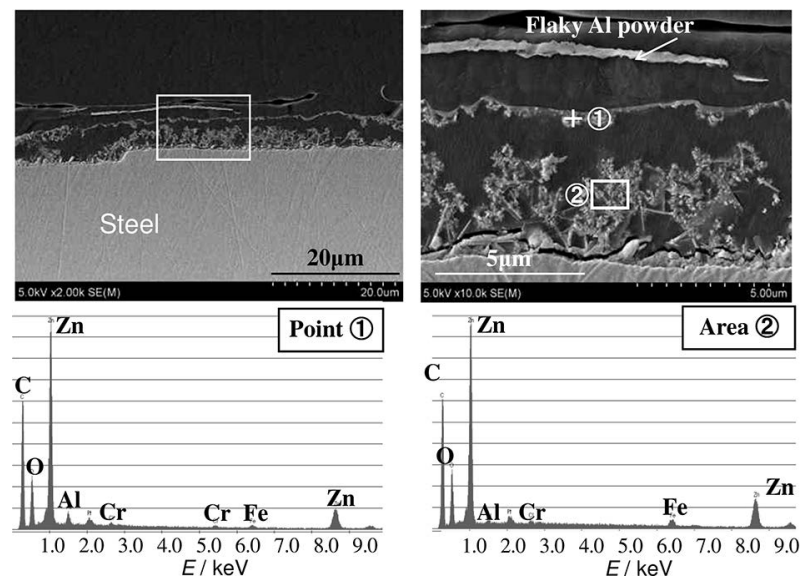

Fig. 7 (a,b) Scanning electron micrographs of cross-section of the sample (F) with $5 \mathrm{phr} \mathrm{Al} \mathrm{immersed} \mathrm{in} \mathrm{the} \mathrm{corrosive}$ solution containing $100 \mathrm{ppm}$ formic acid, $100 \mathrm{ppm}$ acetic acid and $83 \mathrm{ppm} \mathrm{NaCl}$ at $40^{\circ} \mathrm{C}$ for $350 \mathrm{~h}$ and EDS spectra of the marked (c) point 1 and (d) area 2 in (b).

corrosion of this observed region, the epoxy coating was detached from the galvanized steel substrate; embedded resin is present beneath the coating in Fig. 6 .

Fig. 7 shows SEM images and EDS spectra of a crosssection of the coated specimen containing $5 \mathrm{phr}$ Al. A flaky $\mathrm{Al}$ powder is located near the top of the epoxy coating. In contrast to the coated specimen containing Ni powders (Fig. 6), no large corrosion products are developed above the coating. However, corrosion of the $\mathrm{Zn}$ layer proceeded and no continuous $\mathrm{Zn}$ layer remained on the steel substrate. The corrosion products are located only beneath the epoxy coating and consist mainly of $\mathrm{Zn}$ with $\mathrm{Al}$ content being rather low as shown in EDS spectra of the point 1 and area 2 . Since Ni-containing coatings produced the large corrosion products above the epoxy coating (Fig. 6), the morphology of the corroded surface of the Al-containing coating is largely different from that of the Ni-containing coating.

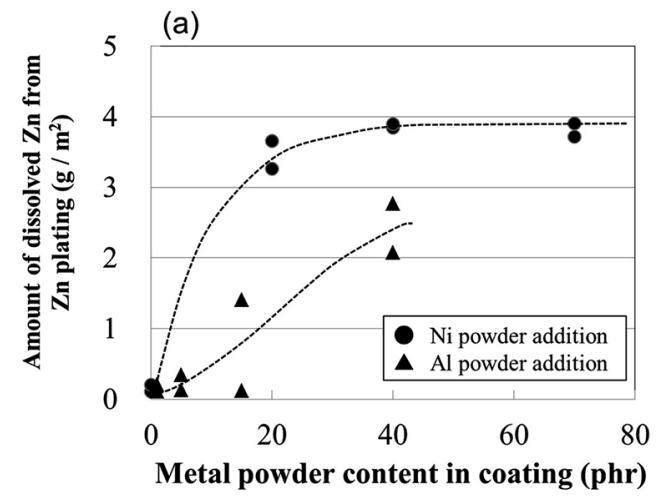

(b)

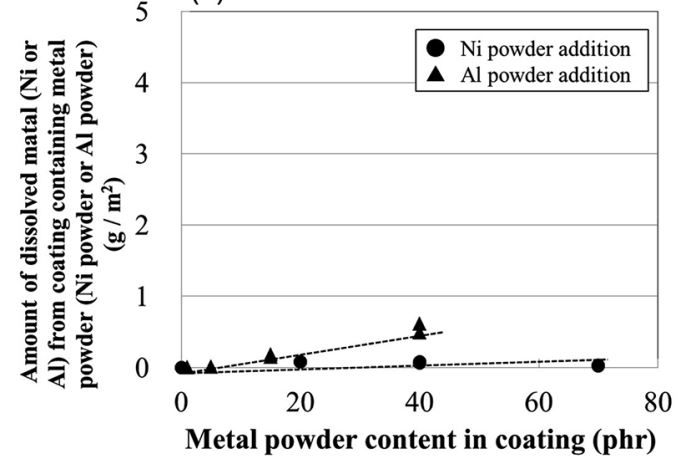

Fig. 8 Change in the amount of dissolved (a) $\mathrm{Zn}$ and (b) Ni and $\mathrm{Al}$ with metal powder content in coating during immersion in the corrosive solution containing $100 \mathrm{ppm}$ formic acid, $100 \mathrm{ppm}$ acetic acid and $83 \mathrm{ppm} \mathrm{NaCl}$ at $40^{\circ} \mathrm{C}$ for $350 \mathrm{~h}$.

Dissolved amounts of $\mathrm{Zn}$, $\mathrm{Ni}$ and $\mathrm{Al}$ during the corrosion tests were measured by ICP analysis and the results are shown in Fig. 8. Both the $\mathrm{Ni}$ and $\mathrm{Al}$ additions increase the dissolved amount of $\mathrm{Zn}$ (Fig. 8(a)), confirming the accelerated corrosion of the $\mathrm{Zn}$ layer by the metallic powders. The corrosion acceleration is larger for the $\mathrm{Ni}$ addition in comparison with the $\mathrm{Al}$ addition. The dissolved amount of $\mathrm{Zn}$ is almost saturated at and above $20 \mathrm{phr} \mathrm{Ni}$ probably because of complete corrosion of the $\mathrm{Zn}$ layer, while the dissolved $\mathrm{Zn}$ increases with an increase in the $\mathrm{Al}$ content. The dissolved amounts of $\mathrm{Zn}$ are always below $10 \%$ of $\mathrm{Zn}$ in the electro-galvanized steel, the remaining $\mathrm{Zn}$ is probably precipitated as corrosion products. For the Nicontaining coatings, the dissolved amount of $\mathrm{Ni}$ was always low even at high Ni contents (Fig. 8(b)). The Ni powders become a cathodic site in the $\mathrm{Ni} / \mathrm{Zn}$ galvanic couple, suppressing the dissolution of $\mathrm{Ni}$. When $\mathrm{Al}$ is added to the coating, the $\mathrm{Al}$ powders dissolves together with $\mathrm{Zn}$, and dissolved $\mathrm{Al}$ increases with the $\mathrm{Al}$ content (Fig. 8(b)).

Approximately $33 \%$ of $\mathrm{Al}$ added to the coating was dissolved into the solution at $40 \mathrm{phr} \mathrm{Al}$. Fe dissolved in the corrosive solution was below a detectable limit in the present study.

\subsection{Measurements of oxygen and water vapor permeability of coatings}

Fig. 9 shows the effect of the amount of $\mathrm{Ni}$ and $\mathrm{Al}$ powders added to the coating on the oxygen gas and water 
(a)
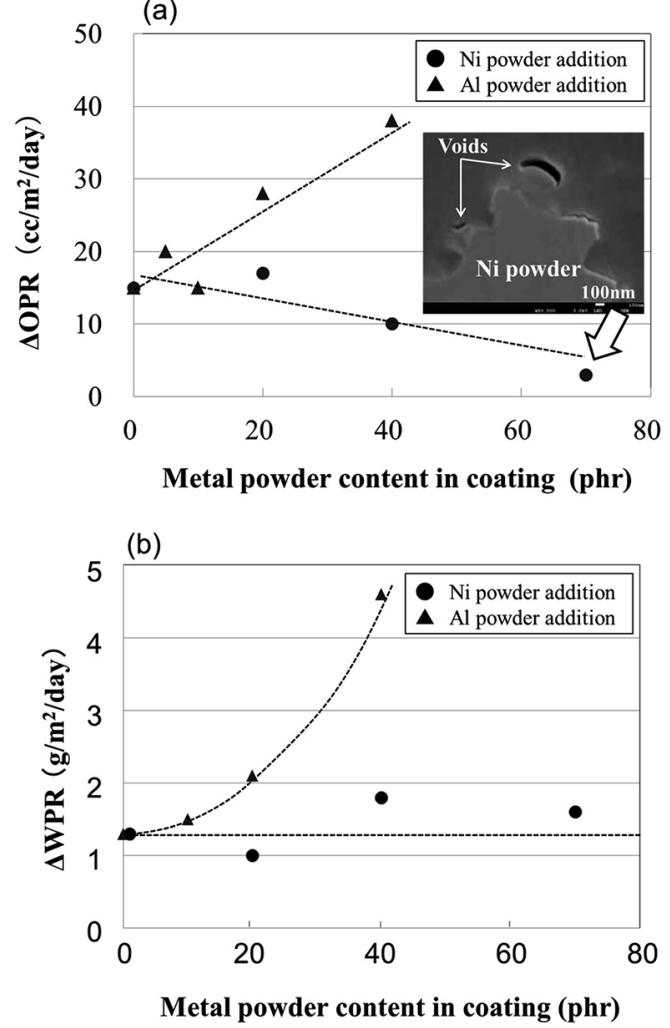

Fig. 9 Correlation between (a) the oxygen gas (b) water vapor barrier property and metal powder content in coating with an inset in (a) showing scanning electron micrograph of a cross-section of the coating with $70 \mathrm{phr} \mathrm{Ni}$.

vapor permeability of the coatings. The oxygen gas barrier nature of the coatings decreases with an increase in the $\mathrm{Ni}$ content, although the water vapor barrier nature is almost unchanged by the Ni addition. The reduced barrier nature to oxygen gas by the addition of Ni may be associated with the presence of voids around the spike-shaped $\mathrm{Ni}$ powders, as shown in the inset SEM image of Fig. 9 (a). In contrast, the barrier nature of the coatings to both oxygen gas and water vapor is largely enhanced by the addition of $\mathrm{Al}$ powders.

\subsection{Polarization measurements}

For a better understanding of the corrosion behavior of the coated specimens, the coated specimens were potentiodynamically polarized in the corrosive solution at $20^{\circ}$ C. Fig. 10 (a) shows the potentiodynamic polarization curves of the coated specimens containing Ni powders. The cathodic current density increases largely with an increase in the Ni content; the coated specimen with 70 phr Ni shows nearly three orders of magnitude higher cathodic current density in comparison with the coated specimen free from Ni. The anodic current density in the vicinity of the corrosion potential also increases with the content of Ni. Thus, the corrosion current density increases with the Ni content. The increase in the anodic current density is less than the cathodic current density, (a)

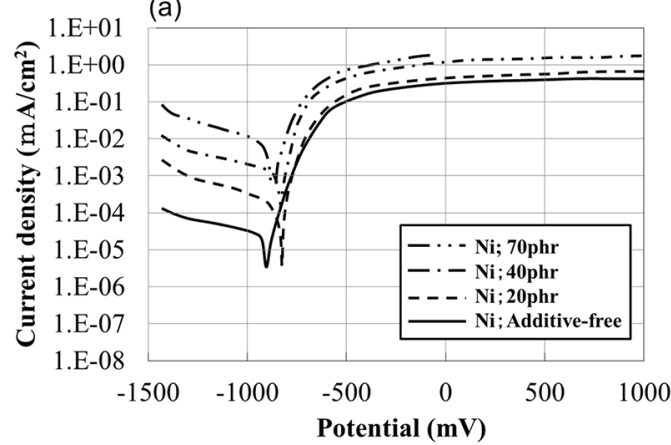

(b)

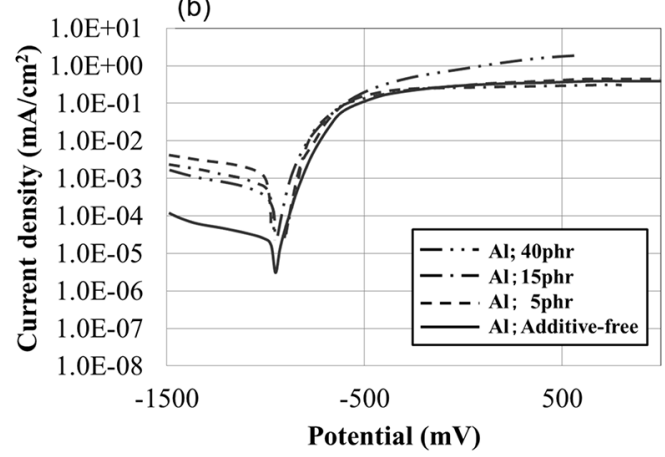

Fig. 10 Potentiodynamic polarization curves of the electrogalvanized steel with epoxy coatings containing (a) $\mathrm{Ni}$ and (b) Al powders measured in the corrosive solution containing $100 \mathrm{ppm}$ formic acid, $100 \mathrm{ppm}$ acetic acid and $83 \mathrm{ppm} \mathrm{NaCl}$ at $20^{\circ} \mathrm{C}$.

resulting in shift of the corrosion potential by $\sim 50 \mathrm{mV}$ to a noble direction by the addition of $\mathrm{Ni}$. The anodic current density becomes almost constant above $-0.5 \mathrm{~V}$ vs $\mathrm{Ag} / \mathrm{AgCl}$, and the steady state anodic current density also increases with an increase in the Ni content. Fig. 10 (b) shows the polarization curves of the coated specimens containing $\mathrm{Al}$ powders. Again, both cathodic and anodic current densities increases with an increase in the $\mathrm{Al}$ content, but the increase is less significant in comparison with the $\mathrm{Ni}$ addition

\subsection{Electrochemical impedance spectroscopy}

Fig. 11 shows Bode plots of the coated specimens with $\mathrm{Ni}$ and $\mathrm{Al}$ powders and Fig.12 shows equivalent circuits used to fit the measured spectra of Fig.11. The impedance at low frequency region decreases with an increase in the $\mathrm{Ni}$ and $\mathrm{Al}$ content, indicating the reduced coating resistance by the metal powder addition. The impedance spectra were fitted using an equivalent circuit of the model 1 in Fig. 12 except for the coated specimen containing 70 phr Ni, for which the model 2 was used to fit the impedance spectrum with two time constants. The $R_{\mathrm{s}}$ is the solution resistance, $\mathrm{CPE}_{1}$ is the constant phase element of the coating, $R_{\mathrm{ct}}$ is the charge transfer resistance of the defect sites of the coating and $\mathrm{CPE}_{2}$ is the constant phase element of the defect sites of the coating. The model 2 was used following the previous studies ${ }^{4), 6)}$. Fig. 13 shows the change in the coating resistance, $R_{\mathrm{c}}$, with the 
(a)

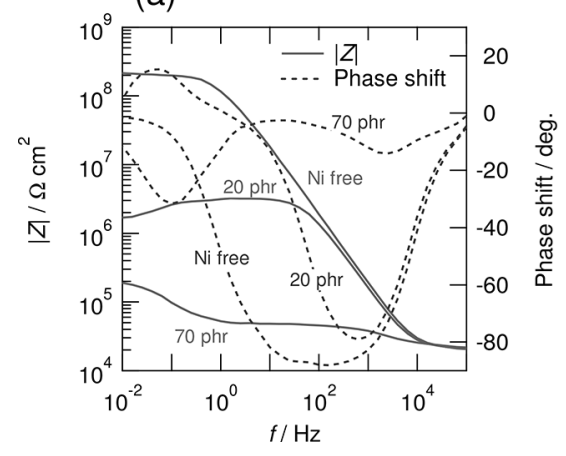

(b)

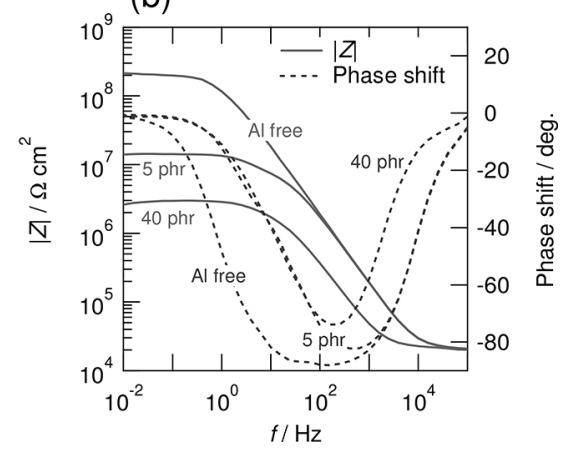

Fig. 11 Bode plots of the electro-galvanized steel with epoxy coatings containing (a) $\mathrm{Ni}$ and (b) Al powders measured in the corrosive solution containing $100 \mathrm{ppm}$ formic acid, $100 \mathrm{ppm}$ acetic acid and $83 \mathrm{ppm} \mathrm{NaCl}$ at $20^{\circ} \mathrm{C}$ (Online version in color.).

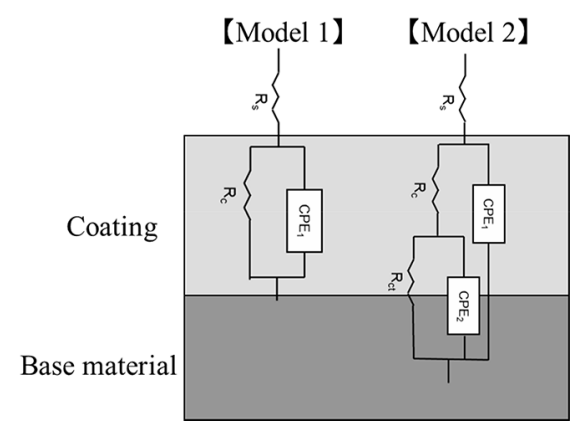

Fig. 12 Two equivalent circuits used to fit the EIS data in this study.

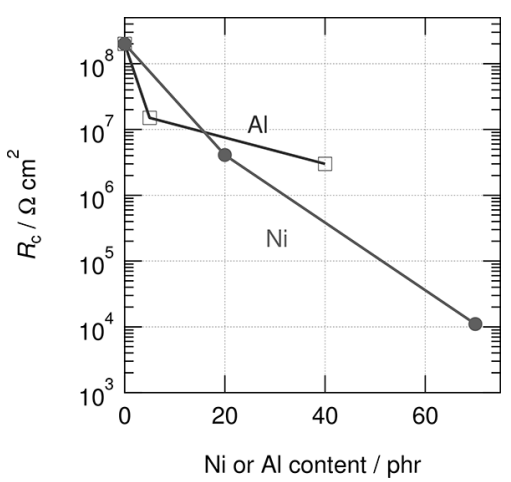

Fig. 13 Change in the coating resistance, $R_{c}$, with the content of $\mathrm{Al}$ or $\mathrm{Ni}$ powders. amount of metal powders. Regardless of the type of metal powders the coating resistance decreases with the amount of metal powders; less protective coatings are formed by the addition of metal powders. The results obtained by EIS measurements, showing the reduced corrosion protection of the coatings by the addition of metallic powders, are consistent with the corrosion tests and polarization measurements.

\section{Discussion}

\subsection{Influence of Ni powder addition in paint film}

In comparison with the coating consisting of only epoxy resin, clear enhanced deterioration of corrosion resistance by the addition of $\mathrm{Ni}$ powders was observed in the corrosion tests. From the SEM observations, the $\mathrm{Zn}$ layer near the Ni powders was severely corroded (Fig. 5). The amount of $\mathrm{Zn}$ dissolved into the corrosive solution during the corrosion tests was much larger for the Ni-containing coatings than that free from metal powders and also those with the same amounts of Al. The potentiodynamic polarization curves revealed that the cathodic current density is highly increased by the addition of Ni powders, because of high cathodic activity of $\mathrm{Ni}$ powders in contact with the $\mathrm{Zn}$ layer. Galvanic corrosion by the addition of $\mathrm{Ni}$ powders promoted the corrosion of the Ni-containing coated steels. The generation of voids around the spikeshaped $\mathrm{Ni}$ powders also appears to enhance the penetration of the corrosive solution through the coating and accelerate the corrosion. It is likely that the increased anodic current density by the addition of $\mathrm{Ni}$ in the potentiodynamic polarization curves is also associated with the increased penetration of the corrosive solution through the coating because of the presence of voids near the Ni powders. The deterioration of the coating resistance was also evident from the EIS measurements; the coating resistance decreases with an increase in the $\mathrm{Ni}$ content.

\subsection{Influence of addition of Al powder to paint film}

Al powders have been added to organic coatings. Gonzalez et al. examined the corrosion resistance of the carbon steel and galvanized steel coated with alkyd and epoxy resins containing $\mathrm{Al}$ powders in $3 \% \mathrm{NaCl}$ solution by EIS measurements. ${ }^{\left.3,{ }^{9}\right)}$ The addition of $\mathrm{Al}$ powders into the coatings improved the corrosion resistance of both the carbon steel and galvanized steel and they explained that the $\mathrm{Al}$ powders provides a cathodic protection of the substrate and the corrosion products precipitating in the pores improve the barrier nature of the coatings. Similar results were also reported by Xue et al. ${ }^{10)}$

In contrast, the addition of flaky $\mathrm{Al}$ powders in the epoxy coatings in the present study accelerated the corrosion of the electro-galvanized steel in the mixed solution containing formic acid, acetic acid and $\mathrm{NaCl}$. The difference of the present study from the previous investigations is probably related to the corrosive 
environment. Seri et al. reported that the corrosion of $1100 \mathrm{Al}$ in $\mathrm{NaCl}$ solutions was accelerated by the addition of acetic acid in the solutions. ${ }^{11)}$ Severe pitting corrosion proceeded during immersion of $1100 \mathrm{Al}$ in $10 \mathrm{~g} \mathrm{~L}^{-1} \mathrm{NaCl}$ solution containing $60 \mathrm{~g} \mathrm{~L}^{-1}$ acetic acid. They reported that Al-acetate complex ion, $\mathrm{Al}(\mathrm{OAc})_{2}{ }^{+}$, is stably present in the $\mathrm{pH}$ range of 3.1-5.5, reducing the $\mathrm{Al}_{2} \mathrm{O}_{3}$ stable $\mathrm{pH}$ range to 5.5-9.1. In the present corrosive solution of $\mathrm{pH} 3.2$ containing acetate and chloride, the corrosion of $\mathrm{Al}$ proceeds probably due to the formation of the Al-acetate complex ions. In fact, more than $30 \%$ of the $\mathrm{Al}$ added to the coating with $40 \mathrm{phr} \mathrm{Al}$ dissolved into the solution during the corrosion tests.

The oxygen gas permeation is clearly reduced by the addition of $\mathrm{Al}$ powders. The water vapor permeation does not increase with the addition of $\mathrm{Al}$ powder. Thus, in contrast to the addition of $\mathrm{Ni}$ powders, the Al-containing coatings do not show the reduced barrier nature. Thus, the increased cathodic current by the addition of $\mathrm{Al}$ powders in the potentiodynamic polarization is not due to the reduced barrier nature of the coatings. The cathodic activity of $\mathrm{Al}$ is most likely to be higher than that of $\mathrm{Zn}$ in this solution.

\subsection{Simultaneous additions of $\mathrm{Ni}$ and $\mathrm{Al}$ powders}

Findings in this study indicate that the separate additions of $\mathrm{Ni}$ and also $\mathrm{Al}$ powders deteriorate the corrosion protection properties of the epoxy coatings on the electro-galvanized steel. In contrast, our previous study revealed that the corrosion protection of the Ni-containing epoxy coatings were highly improved by the simultaneous addition of $\mathrm{Al}$ powders. This is contrast to the reduced corrosion protection of the $\mathrm{Al}$-added coatings without $\mathrm{Ni}$ in this study. Thus, some synergistic effect plays an important role in improving the corrosion protection by the simultaneous additions of $\mathrm{Ni}$ and $\mathrm{Al}$ powders.

As discussed in the previous study, ${ }^{8)}$ the flaky $\mathrm{Al}$ powders were often located at the bottom of the epoxy coatings, which separated the particulate Ni powders from the $\mathrm{Zn}$ layer. Severe $\mathrm{Zn}$ corrosion by forming a $\mathrm{Ni} / \mathrm{Zn}$ galvanic couple is effectively suppressed by the addition of $\mathrm{Al}$ powders. However, the present study disclosed that the $\mathrm{Zn}$ corrosion was also accelerated by the addition of $\mathrm{Al}$ and no $\mathrm{Zn}$ layer was remained continuously as shown in Fig. 7. This is contrast to the almost un-corroded $\mathrm{Zn}$ layer beneath the flaky $\mathrm{Al}$ powder, above which a Ni powder was present..$^{8)}$ One possible explanation of the suppression of corrosion of $\mathrm{Zn}$ and $\mathrm{Al}$ by the simultaneous additions of $\mathrm{Ni}$ and $\mathrm{Al}$ powders is an increase in $\mathrm{pH}$ of the corrosive solution incorporated into the coating. $\mathrm{Ni}$ is the noblest element among $\mathrm{Ni}, \mathrm{Zn}$ and $\mathrm{Al}$ such that the Ni powders acts as a cathodic site. The cathodic reaction is either hydrogen evolution or oxygen reduction, resulting in an increase in $\mathrm{pH}$. If $\mathrm{pH}$ increased to $>5.5$ where $\mathrm{Al}_{2} \mathrm{O}_{3}$ is stable, the corrosion of $\mathrm{Al}$ is suppressed by forming a passive film. The $\mathrm{Zn}$ corrosion is also suppressed with an increase in $\mathrm{pH}$.

The present study suggests that the corrosion protection properties of the organic coatings are improved by simultaneous addition of $\mathrm{Ni}$ and $\mathrm{Al}$ powders, even though the separate additions of these powders accelerates the corrosion. Findings in this study open up a new design principle of the composite organic coatings containing metallic powders. Detailed understanding the role of metal powders in the organic coatings in corrosion process is a key to design corrosion resistant coatings with different metal powders, which plays synergistic roles in improving the corrosion resistance.

\section{Conclusions}

Coatings containing either particulate Ni powders or flaky $\mathrm{Al}$ powders were prepared on electro-galvanized steel, and their corrosion resistance in a mixed aqueous solution containing $100 \mathrm{ppm}$ formic acid, $100 \mathrm{ppm}$ acetic acid and $83 \mathrm{ppm} \mathrm{NaCl}$ at $40^{\circ} \mathrm{C}$ for $350 \mathrm{~h}$ was investigated by surface observations, SEM observations and solution analysis. In addition, potentiodynamic polarization, EIS and oxygen gas and water vapor permeation studies were conducted. The following conclusions were drawn.

(1) When Ni powders are added to the epoxy coating, the corrosion resistance deteriorates as the amount of $\mathrm{Ni}$ powders increases from 0 to $70 \mathrm{phr}$. At $70 \mathrm{phr} \mathrm{Ni}$, the entire specimen surface is covered with white rust.

(2) Corrosion is also accelerated by the addition of $\mathrm{Al}$ powders, although the corrosion morphology is different from the coatings with Ni powders. No corrosion products are formed on the epoxy coating.

(3) Corrosion products are preferentially formed on the coating near the Ni powders because of $\mathrm{Ni} / \mathrm{Zn}$ galvanic corrosion when $\mathrm{Ni}$ is added to the coating. When $\mathrm{Al}$ powders are added, more uniform $\mathrm{Zn}$ dissolution occurs. The dissolved $\mathrm{Zn}$ increases as the content of the metallic powders in the coating increases.

(4) The addition of both $\mathrm{Ni}$ and $\mathrm{Al}$ powders in the coating enhances the cathodic activity of the coated specimens. The coating resistance is reduced with an increase in the metallic powders. As a consequence, the corrosion is accelerated by the addition of metallic powders.

(5) The gas permeability increases with $\mathrm{Ni}$ addition because of void formation around Ni powders, while $\mathrm{Al}$ addition improves the gas barrier nature.

(6) Therefore, the improved corrosion resistance by the simultaneous additions of $\mathrm{Ni}$ and $\mathrm{Al}$ powders in the epoxy coating is not explained from the corrosion behavior of the coatings containing either $\mathrm{Al}$ or $\mathrm{Ni}$ powders. The enhanced cathodic activity at Ni sites may increase the local $\mathrm{pH}$ in the coating and the formation of the $\mathrm{Ni} / \mathrm{Zn}$ galvanic couple is avoided by the insertion of flaky $\mathrm{Al}$ powders, probably contributing to the improved corrosion protection of the coatings with both $\mathrm{Al}$ and Ni powders. 


\section{References}

1) S. Higuchi and M. Ōbu, Jitsumu Hyōmen Gijutsu, 261, p.452 (1975)

2) S. Suzuki, H. Ogata, S. Umino and C. Kato, Tetsu-toHagane, 89, p.1 (2003).

3) S. Gonzalez, F. Caceres, V. Fox and R.M. Souto, Prog. Org. Coat., 46, pp.317-323 (2003).

4) Y. Liang, F.C. Liu, M. Nie, S.Y. Zhao, J.D. Lin and E.H. Han, J. Mater. Sci. Tech., 29, pp.353-358 (2013).

5) B. Nikravesh, B. Ramezanzadeh, A.A. Sarabi and S.M. Kasiriha, Corros. Sci., 53, pp.1592-1603 (2011)

6) S.Y. Arman, B. Ramezanzadeh, S. Farghadani, M. Mehdipour and A. Rajabi, Corros. Sci., 77, pp. 118-127 (2013).
7) M. Nakamura and Y. Yamamoto, Technical Paper of Society of Automotive Engineers of Japan, 956, p.221 (1995).

8) H. Ogata and H. Habazaki, ISIJ Int., in press.

9) S. González, I.C. Mirza Rosca and R.M. Souto, Prog. Org. Coat., 43, pp. 282-285 (2001).

10) L. Xue, L. Xu and Q. Li, J. Mater. Sci. Technol., 23, pp.563$567(2007)$.

11) O. Seri, Y. Hoshi and M. Sakai, J. Jpn. Inst. Light Met., 55 , pp.175-180 (2005).

要 旨

最近, 筆者らは鱗片状 $\mathrm{Al}$ 粉と粒子状 $\mathrm{Ni}$ 粉とを混合添加したエポキシ樹脂塗膜を電気亜鉛めっき鋼板上 に被覆することにより燃料タンク内面の耐食性が改善されることを報告した。この有機被覆電気覀鉛めっ き鋼板の腐食挙動に及ぼす塗膜中の $\mathrm{Ni}$ 粉および $\mathrm{Al}$ 粉の各々の役割を理解するために, $\mathrm{Ni}$ 粉または $\mathrm{Al}$ 粉 のいずれかを含むエポキシ樹脂被覆電気亜鉛めっき鋼板を作製し, 蟻酸, 酢酸および $\mathrm{NaCl}$ を含む水溶液 中での腐食浸漬試験，動電位分極測定，電気化学インピーダンス分光法(EIS) 測定，ならびに酸素ガスお よび水蒸気透過測定を実施し腐食挙動を調査した。その結果, 塗膜中の $\mathrm{Ni}$ および $\mathrm{Al}$ 粉は，いずれも腐食 を加速した．分極曲線よりアノードおよびカソード電流の増加を，EIS 測定においては， Ni および $\mathrm{Al}$ 粉 の添加による塗膜抵抗の減少が確認された． Ni および $\mathrm{Al}$ 粉の両方を含有するコーティングの改善された

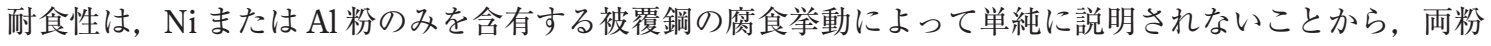
の耐食性改善の相乗効果について議論した.

キーワード＼cjkstart腐食，有機皮膜，金属粉，亜鉛めっき鋼，耐劣化ガソリン性 